\title{
MICROBIOLOGICAL CHARACTERISTIC AND FERMENTABILITY OF KING GRASS (Pennisetum hybrid) SILAGE TREATED BY LACTIC ACID BACTERIA- YEAST INOCULANTS CONSORTIUM COMBINED WITH RICE BRAN ADDITION
}

\author{
A. Sofyan ${ }^{1}$, L.M. Yusiati ${ }^{2}$, Y. Widyastuti ${ }^{3}$ and R. Utomo ${ }^{2}$ \\ ${ }^{1}$ Research Unit for Processes Development and Chemical Engineering (BPPTK), \\ Indonesian Institute of Sciences (LIPI), \\ Jl. Jogja-Wonosari Km. 31, Gading, Playen, Gunungkidul, DIY 55861 - Indonesia \\ ${ }^{2}$ Faculty of Animal Sciences, Gadjah Mada University, \\ Jl. Fauna No.3, Bulaksumur, Yogyakarta 55281 - Indonesia \\ ${ }^{3}$ Research Center for Biotechnology, Indonesian Institute of Sciences (LIPI) \\ Jl. Raya Bogor Km. 46, Cibinong, Jawa Barat 16911 - Indonesia \\ Corresponding E-mail: sofyan_lipi@yahoo.co.id
}

Received October 24, 2011; Accepted November 20, 2011

\begin{abstract}
ABSTRAK
Penelitian ini dilakukan untuk mengevaluasi pengaruh konsorsium inokulum yang terdiri dari Lactobacillus plantarum (Lp) yang Saccharomyces cerevisiae $(\mathrm{Sc})$ yang dikombinasikan dengan penambahan dedak padi terhadap karakteristik mikrobiologi dan fermentabilitas silase rumput raja (Pennisetum hybrid). Efektivitas penambahan inokulum (kontrol, Lp, Lp+Sc) dan dedak padi (0, 5, $10 \%$ ) disusun dalam Rancangan Acak Lengkap pola Faktorial (3x3). Peubah yang diamati terdiri dari jumlah koloni mikroba (bakteri asam laktat, yeast dan clostridia), produksi gas, asam lemak volatil (VFA) dan amonia (NH3). Hasil penelitian menunjukkan bahwa jumlah koloni clostridia pada silase yang diberi perlakuan Lp dan Lp+ Sc berkisar 37,5\% dan 68,7\% lebih rendah dari kontrol. Penambahan inokulum dan dedak padi nyata $(\mathrm{P}<0,05)$ meningkatkan fermentabilitas, namun tidak berpengaruh nyata $(\mathrm{P}>0,05)$ terhadap produksi VFA dan $\mathrm{NH}_{3}$. Produksi gas dari fraksi silase terfermentasi yang diberi perlakuan inokulum Lp $(49,5 \mathrm{ml})$ dan $\mathrm{Lp}+\mathrm{Sc}(47,9 \mathrm{ml})$ lebih tinggi dibandingkan dengan silase tanpa perlakuan $(46,6 \mathrm{ml})$. Dapat disimpulkan bahwa penggunaan konsorsium inokulum $L$. plantarum dan $S$. cerevisiae dengan penambahan dedak padi meningkatkan fermentabilitas dan menurunkan koloni clostridia pada silase rumput raja.

Kata kunci: clostridia, fermentabilitas, L. plantarum, S. cerevisiae, silase
\end{abstract}

\begin{abstract}
This research was conducted to evaluate the effect of inoculants consortium consisted of Lactobacillus plantarum (Lp) and Saccharomyces cerevisiae (Sc) and combined with rice bran addition on microbiological characteristic and fermentability of king grass (Pennisetum hybrid) silage. Effectivity of treatments was assessed by addition of inoculants (control, $\mathrm{Lp}, \mathrm{Lp}+\mathrm{Sc}$ ) and level of rice bran $(0,5$ and $10 \%)$ which were arranged on Completely Randomized Design with Teatments Factors (3x3). The variables measured were total colonies of microbes (lactic acid bacteria, yeast and clostridia), total gas production, volatile fatty acids (VFA) and ammonia (NH3). Results showed that clostridial colonies counted on silage treated by Lp and Lp+Sc around $37.5 \%$ and $68.7 \%$ in which lower than control. Addition of inoculants and rice bran increased fermentability of silage significantly $(\mathrm{P}<0.05)$, however treatment had no affected $(\mathrm{P}>0.05)$ on production of VFA and $\mathrm{NH}$ 3. Gas production from silage fermentable fraction with inoculation of $\mathrm{Lp}(49.5 \mathrm{ml})$ and $\mathrm{Lp}+\mathrm{Sc}(47.9 \mathrm{ml})$ higher than untreated silage (46.6 ml). It was concluded that the use of inoculants consortium consisted of L. plantarum and $S$. cerevisiae with rice bran addition improved fermentability and reduced clostridial colony in king grass silage.
\end{abstract}

Keywords: clostridia, fermentability, L. plantarum, S. cerevisiae, silage 


\section{INTRODUCTION}

Livestock development is significant contribution for supplying foodstuff from animal product. However, limitation of forage supply implies the low productivity of ruminant. Preservation of forage using ensilage method is one attempt to maintain the forage stock. In contrast, silage technology has not been widely applied by farmers because the lacking of knowledge in silage technology transfer (Mannetje, 2000) and high level of spoilage due to failure to achieve anaerobic conditions.

The process of silage to produce lactic acid can be constrained by the presence of oxygen, so that the density and anaerobic conditions could not be maximized in silo. This because of the anaerobic conditions are not achieved, a high level of damage at silage occurred by indication of increasing clostridia colonies and butyric acid content in silage (Vissers et al., 2007).

Efforts to improve the anaerobic conditions necessary for quality silage can be maintained. One effort that might be done to improve the anaerobic conditions in the silage by addition of Saccharomyces cerevisiae. According to Chaucheyras et al. (1995), S. cerevisiae can reduce aerobic conditions because it activities require oxygen. The presence of $S$. cerevisiae can support the growth of lactic acid bacteria (LAB) (Gobbetti, 1998).

In addition, $S$. cerevisiae on silage has the potential to support the growth of $\mathrm{LAB}$ which has been used as silage inoculant. Therefore, research on the use of $S$. cerevisiae and its interaction with $\mathrm{LAB}$ as silage inoculant needs to be done. The objective of this study was to evaluate effect of inoculants consortium consisted of $L$. plantarum and $S$. cerevisiae $(\mathrm{Sc})$ and combination of addition of soluble carbohydrates (rice bran) on microbiological characteristics and fermentability of king grass silage.

\section{MATERIALS AND METHODS}

\section{Forage and Inoculant Preparation}

King grass $(P$. hybrid) for silage making was harvested at the age of 60 days and obtained from the field laboratory at UPT. BPPTK- LIPI Yogyakarta. Inoculants consisted of lactic acid bacteria (L. plantarum) and yeast (S. cerevisiae) which were isolated and identified in previous study (Sofyan et al., 2011). Inoculants had been prepared by pre-culturing of $L$. plantarum on MRSB (deMann Rogossa Sharpe Broth) and yeast on MEB (Malt Extract Broth) medium which was incubated during 24 hours at $37^{\circ} \mathrm{C}$ and $30^{\circ} \mathrm{C}$ respectively for $\mathrm{LAB}$ and yeast. The number of colonies of L. plantarum was $10^{8} \mathrm{cfu} / \mathrm{ml}$ and S. cerevisiae $10^{7} \mathrm{cfu} / \mathrm{ml}$ in medium.

\section{Treatment}

The effectiveness of inoculant on silage quality was evaluated by adding inoculants and rice bran as a source of soluble carbohydrate (water soluble carbohydrate / WSC) in king grass silage. The treatments were arranged on completely randomized design with factorial treatment were inoculants (control, Lp, Lp+Sc) and addition of rice bran $(0,5$, and $10 \%)$ with 3 replication as mentioned on Table 1.

The silage making process consisted of 3 stages, were: 1) preparation of materials, 2) mixing processes referred to the formula and treatment, 3) packaging and incubation. Preparation of feed material was conducted by chopping the grass with shredded size $1-3 \mathrm{~cm}$. Previously, grass wilted during 24 hours in order to increase dry matter content.

Inoculant $1 \%(\mathrm{v} / \mathrm{w})$ added into silage and addition of water in order to adjust moisture content up to $75 \%$. After all the ingredients mixed homogeneous, packed in plastic containers (5 $\mathrm{kg} /$ pack) and incubated for 21 days. Samples for in vitro digestibility analysis were prepared by freeze-drying method using a freeze dryer Leybold-Heraeus GT Lyovac type-2 (Peterswan Ltd., Edinburgh) at $-20^{\circ} \mathrm{C}$ for 20 hours. Then, samples were sieved by $1.0 \mathrm{~mm}$ screening.

\section{Microbiological Characteristics Evaluation}

Microbiological characteristics assessed by counting microbes (LAB, yeasts and clostridia) colonies. Each of microbes was grown on selective media MRSA, MEA and RCA (Reinforced Clostridial Agar) respectively for $\mathrm{LAB}$, yeasts and clostridia. Silage sample was prepared for enumeration of microbial colonies which was conducted by taking $50 \mathrm{~g}$ samples from each replication, added by $50 \mathrm{ml}$ of sterile distilled water and stirred for 5 minutes in aseptic condition. Amount of $3 \mathrm{ml}$ supernatant and homogenized in aseptic conditions. Supernatant obtained at each treatment was grown on selective 
Table 1. Inoculant and Rice Bran Addition into King Grass Silage

\begin{tabular}{llll}
\hline \multirow{2}{*}{ Inoculants } & \multicolumn{3}{c}{ Level of Rice Bran } \\
\cline { 2 - 4 } & $0 \%$ & $5 \%$ & $10 \%$ \\
\hline Control (A) & A0 & A5 & A10 \\
Lp (B) & B0 & B5 & B10 \\
Lp+Sc (C) & C0 & C5 & C10 \\
\hline
\end{tabular}

Lp (L. plantarum), Sc (S. cerevisiae)

medium with serial dilution at $10^{2}, 10^{3}, 10^{4}, 10^{5}$ and $10^{6}$ of LAB (MRSA) and Clostridia (RCA) in which incubated at $37{ }^{\circ} \mathrm{C}$ while yeasts (MEA) incubated at $30^{\circ} \mathrm{C}$ with the same incubation time (24 hours).

\section{Fermentability Evaluation}

Evaluation of silage fermentability, VFA (Volatile Fatty Acids) and $\mathrm{NH}_{3}$ (ammonia) production measured by the total gas production. Silage samples that had been freeze-dried, ground with a mortar and sieved by a filter with a hole size of $1 \mathrm{~mm}$. Measurement of gas production refers to Menke et al. (1979) and Blümmel et al. (1997) modified by Jayanegara et al. (2009a). Silage samples $380 \mathrm{mg}$ (dry matter $86.4 \%$ ) was placed into the syringe to the pre-incubation for 24 hours at a temperature of $39^{\circ} \mathrm{C}$.

Rumen fluid (10 ml) and buffer solution (20 $\mathrm{ml}$ ) inserted into syringe with saturated $\mathrm{CO}_{2}$. Composition of buffer solution per $100 \mathrm{ml}$ rumen fluid consisted of macrominerals $(23.7 \mathrm{ml})$, micro-minerals $(0.012 \mathrm{ml})$, bicarbonate buffer solution $(23.7 \mathrm{ml})$, resazurin $4 \%(0.122 \mathrm{ml})$, reducing solution $(4.96 \mathrm{ml})$ and distilled water (47.5 ml) (Menke et al., 1979). Rumen fluid was taken from fistulated beef cattle (Ongole crossbred) in which was conditioned by feeding standard (feed composition consisted of $60 \%$ forage and $40 \%$ concentrate).

Evaluation of fermentability and in vitro digestibility were arranged in factorial completely randomized design with 2 factors of treatments. Each treatment consisted of 3 replications with 2 sub samples. Pangola grass (Digitaria decumbens) was used as standard sample and each syringes containing silage, standard samples and blank were randomly allocated in the incubator. Incubation was carried out for 48 hours and gas production was observed at $0,1,2,4,6,8,12,18$, 24, 36 and 48 hours after incubation.

Gas production kinetics was calculated based on the exponential equation according to Ørskov and McDonald (1979). The estimated value of a, $\mathrm{b}$, c were calculated by a fitting curve method using Neway Software program (Rowett Research Institute, Aberdeen, UK) that installed at Microsoft Office Excel $2007^{\circledR}$ and developed by Chen (1997).

Production of VFA and $\mathrm{NH}_{3}$ were measured after sample was incubated in a syringe containing rumen fluid-buffer. Analysis of VFA was performed by gas chromatography method as followed by Frigens et al. (1998) and $\mathrm{NH}_{3}$ analysis using spectrophotometric method (Broderick and Kang, 1980). Sample preparation was conducted by taking samples of rumen fluidbuffer after 48 hours incubation which were centrifuged at $3000 \mathrm{rpm}$ for 15 minutes followed to centrifugation at $10,000 \mathrm{rpm}$ for 10 minutes. A total of $0.2 \mathrm{ml}$ supernatant was added into a microtube and added $1 \mathrm{ml}$ meta-phosphate acid $25 \%(\mathrm{w} / \mathrm{v})$. Samples of $1 \mu \mathrm{l}$ injected into the packed column type GP10\% SP-1200/1\% $\mathrm{H}_{3} \mathrm{PO}_{4}$ on 80/100 Chromosorb WAW (Supelco, Bellefonte, PA) on GC (Shimadzu 8-A) and equipped with FID (Flame Ionization Detector).

Sample preparation for $\mathrm{NH}_{3}$ analysis was performed by taking $0.4 \mathrm{ml}$ of rumen fluid-buffer after $48 \mathrm{~h}$ incubation, added $0.2 \mathrm{ml}$ solution $\mathrm{A}$ (10\% sodium tungstate) and $0.2 \mathrm{ml}$ solution B $\left(\mathrm{H}_{2} \mathrm{SO}_{4} 1 \mathrm{~N}\right)$, then centrifuged at $3000 \mathrm{rpm}$ for 15 minutes and followed centrifugation at 10,000 $x g$ for 10 minutes. Amount of $10 \mu \mathrm{l}$ of supernatant was diluted with $10 \mu \mathrm{l}$ distilled water, added 2.5 $\mathrm{ml}$ of solution $\mathrm{C}$ (phenol solution) and $2.5 \mathrm{ml}$ of solution D (sodium hypo-chloride 5\%). Mixture solution was heated at $40^{\circ} \mathrm{C}$ for 30 minutes and then read the sample absorbance with the spectrophotometer in the wavelength $(\lambda) 630 \mathrm{~nm}$.

\section{Data Analysis}

Silage microbial colonies characteristic data were statistically analyzed descriptively. Data of gas production, VFA and $\mathrm{NH}_{3}$ were analyzed with analysis of variance (ANOVA) and if among the treatments showed significant differences (P $<0.05)$ followed by orthogonal contrast test 
(Gomez and Gomez, 1984).

\section{RESULTS AND DISCUSSION}

\section{Microbiological Characteristics of Silage}

Microbiological characteristics of silage which includes the number of colonies of lactic acid bacteria (LAB), yeasts, and Clostridia are shown in Table 2. In general, the number of colonies (colony forming unit/cfu) of LAB grown on MRSA at $6.5 \times 10^{6}$ to $3.7 \times 10^{7} \mathrm{cfu} / \mathrm{g}$, while the number of yeast colonies were counted MEA medium in the range 2.5 to $6.5 \times 10^{6} \mathrm{cfu} / \mathrm{g}$, where the number of colonies of LAB and yeast does not show difference between treatments (Table 2).

Effect of inoculant on the number of LAB colonies was significant influenced by the type isolate. Addition of LAB inoculant ( $L$. species casei) had no effect on the number of $\mathrm{LAB}$ and yeast colonies in silage, while the inoculant of L. buchneri increased LAB colonies $50.7 \%$ and reduce yeast colonies up to $65.6 \%$ compared with controls in which the population of LAB and yeasts on silage respectively $5.2 \times 10^{5} \mathrm{cfu} / \mathrm{g}$ and

Table 2. The Number of Microbial Populations in King Grass

\begin{tabular}{|c|c|c|c|c|}
\hline \multirow{2}{*}{$\begin{array}{l}\text { Inoculant } \\
\text { Treatment }\end{array}$} & \multicolumn{3}{|c|}{ Level of Rice Bran } & \multirow{2}{*}{ Average } \\
\hline & $0 \%$ & $5 \%$ & $10 \%$ & \\
\hline LAB & \multicolumn{4}{|c|}{--- x 107 cfu/g --- } \\
\hline Control & 3.7 & 0.9 & 0.8 & 1.8 \\
\hline Lp & 1.5 & 0.7 & 1.6 & 1.3 \\
\hline $\mathrm{Lp}+\mathrm{Sc}$ & 2.0 & 1.1 & 0.6 & 1.2 \\
\hline Average & 2.4 & 0.9 & 1.0 & \\
\hline Yeast & \multicolumn{4}{|c|}{------ x $10^{6} \mathrm{cfu} / \mathrm{g}$} \\
\hline Control & 4.0 & 2.5 & 3.3 & 3.3 \\
\hline Lp & 4.8 & 3.3 & 5.0 & 4.4 \\
\hline $\mathrm{Lp}+\mathrm{Sc}$ & 5.3 & 6.5 & 5.3 & 5.7 \\
\hline Average & 4.7 & 4.1 & 4.5 & \\
\hline Clostridia & \multicolumn{4}{|c|}{------ x $10^{5}$ cfu/g ------ } \\
\hline Control & 11.0 & 3.0 & 2.2 & 5.3 \\
\hline Lp & 4.5 & 1.9 & 2.8 & 3.0 \\
\hline $\mathrm{Lp}+\mathrm{Sc}$ & 3.3 & 1.0 & 1.2 & 1.8 \\
\hline Average & 6.2 & 2.0 & 2.1 & \\
\hline
\end{tabular}

$4.2 \times 10^{5} \mathrm{cfu} / \mathrm{g}$ (Nishino et al., 2004).

Referred to Filya (2003), mentioned that the number of colonies of LAB, yeasts and fungi in silage influenced by the type of bacterial inoculant, length of incubation and type of materials used in silage making. A longer time of incubation affected increasing the BAL and declining yeasts and fungal colonies in silage. This is related to the accumulation of lactic acid which increase in length of incubation. Furthermore, it was followed by decreasing $\mathrm{pH}$ which implied inhibiting growth of yeasts and fungi.

The number of clostridia in silage was grown on RCA medium showed that clostridial colonies was ranging from $5.3 \times 10^{6} \mathrm{cfu} / \mathrm{g}$ on control, it colonies decreased into $3.0 \times 10^{5} \mathrm{cfu} / \mathrm{g}$ and $1.8 \mathrm{x}$ $10^{5} \mathrm{cfu} / \mathrm{g}$ were found at silage treated by $L$. plantarum and combination L. Plantarum + S.cerevisiae, respectively.

The highest decreasing number of clostridial colonies were found at silage treated $\mathrm{LAB}+$ yeast inoculant consortium combined with rice bran addition. This indicated that $S$. cerevisiae in silage had contributing in clostridial inhibition. Furthermore, effect of adding rice bran in a silage inoculant had enhancing production of lactic acid. The presence of lactic acid in silage had an impact in declining clostridial colonies. Due to clostridia growth would be inhibited by decreasing $\mathrm{pH}(\mathrm{pH}$ approximately 4) in which in lower $\mathrm{pH}$ clostridia difficult to grow. The $\mathrm{pH}$ optimum for clostridia growth around at neutral range $\mathrm{pH}$ 7.0-7.4 (McDonald et al., 1991).

Lactic acid bacteria had ability to produce bacteriocin which was a secondary metabolite could inhibits pathogenic bacteria such as clostridia. It can synthesize antibacterial compounds 'bacteriocin' which has been shown to inhibit the pathogenic gram-positive bacteria (Micrococcus luteus) and gram-negative bacteria (Pseudomonas aeruginosa) (Gollop et al., 2005) and Clostridium tyrobutyricum (Thuault et al., 1991). Bacteriocin that produced by LAB was widely used as bio-preservative agent to prevent spoilage of food or feed by Clostridium botulinum (Montvile and Winskowski, 1997).

Lowering number of clostridial colonies in silage inoculated LAB+yeast consortium indicated that $S$. cerevisiae ability to produce antibacterial substances. S. cerevisiae produced oxylipin that inhibit clostridia growth (Strauss et al., 2005). Presence of those active compounds 
Table 3. Total Gas Production (p), Potentially Soluble Fraction (a+b) and Gas Production Rate (c) of King Grass Silage Incubated for 48 Hours

\begin{tabular}{llcccc}
\hline \multirow{2}{*}{ Treatment } & Parameter & \multicolumn{3}{c}{ Rice Bran Level } & \multirow{2}{*}{ Average } \\
\cline { 3 - 5 } Control & $\mathrm{p}(\mathrm{ml})$ & 34.18 & 38.44 & 36.46 & 36.36 \\
& $\mathrm{a}+\mathrm{b}(\mathrm{ml})$ & 47.93 & 47.71 & 44.22 & $46.62^{\mathrm{A}}$ \\
& $\mathrm{c}(\mathrm{ml} / \mathrm{h})$ & 0.027 & 0.036 & 0.039 & 0.034 \\
& $\mathrm{p}(\mathrm{ml})$ & 34.18 & 36.80 & 38.13 & 36.37 \\
Lp & $\mathrm{a}+\mathrm{b}(\mathrm{ml})$ & 48.91 & 50.59 & 41.03 & $49.51^{\mathrm{C}}$ \\
& $\mathrm{c}(\mathrm{ml} / \mathrm{h})$ & 0.026 & 0.029 & 0.045 & 0.030 \\
& $\mathrm{p}(\mathrm{ml})$ & 33.23 & 37.71 & 39.16 & 36.70 \\
Lp+Sc & $\mathrm{a}+\mathrm{b}(\mathrm{ml})$ & 47.44 & 48.85 & 47.47 & $47.92^{\mathrm{B}}$ \\
& $\mathrm{c}(\mathrm{ml} / \mathrm{h})$ & 0.026 & 0.033 & 0.040 & 0.033 \\
& $\mathrm{p}(\mathrm{ml})$ & $33.86^{\mathrm{a}}$ & $37.65^{\mathrm{b}}$ & $37.91^{\mathrm{b}}$ & \\
& $\mathrm{a}+\mathrm{b}(\mathrm{ml})$ & 48.09 & 49.05 & 46.90 & \\
Average & $\mathrm{c}(\mathrm{ml} / \mathrm{h})$ & $0.027^{\mathrm{a}}$ & $0.033^{\mathrm{b}}$ & $0.038^{\mathrm{c}}$ & \\
\hline
\end{tabular}

Lp (L. Plantarum); Sc (S. Cerevisie)

implied to support the role of bacteriocin produced by $\mathrm{LAB}$ in inhibiting clostridia. Synergism of $\mathrm{LAB}$ and $S$. cerevisiae for inhibiting growth of clostridia in silage was supported clostridial colonies data that silage treated with $\mathrm{LAB}+$ yeast which tend to be lower than single inoculant (LAB) or control.

The number of clostridial colonies was lower in the inoculated silage, in which had implications for minimizing the silage deterioration. Clostridia in silage converted protein fraction into ammonia by proteolysis enzymes (McDonald et al., 1991), and capable of converting lactic acid into butyric acid accompanied by the formation of hydrogen and carbon dioxide (Stefanie et al., 2000)

\section{Gas Production Kinetics}

Fermentability parameters and digestibility in vitro of silage evaluated by analyzing the kinetics of gas production during incubation, production of VFA and $\mathrm{NH}_{3}$. Kinetics of gas production and fermentability of silage during incubation of 48 hours which included gas production from potentially soluble fraction $(a+b)$, rate of gas production (c) were shown at Table 3.
The highest gas production $(39.2 \mathrm{ml})$ obtained from silage received inoculant consortium treatment with addition of $10 \%$ rice bran, while it was without rice bran addition showed that lowering in gas production $(33.2 \mathrm{ml})$. Inoculant treatment significantly $(\mathrm{P}<0.05)$ increased gas production from the total fraction of silage $(a+b)$ with gas production rate was relatively similar $(0.029$ to $0.034 \mathrm{ml} / \mathrm{h})$. The highest of gas production was found from silage treated by L. plantarum $(50.0 \mathrm{ml})$, and followed by $L$. plantarum + S.cerevisiae $(48.2 \mathrm{ml})$ which was significantly higher than control $(46.9 \mathrm{ml})$.

Addition of rice bran were significant difference $(\mathrm{P}<0.05)$ on increasing rate of gas production during fermentation of silage. Silage added by rice bran (5-10\%) had a gas production rate around 0.032 to $0.037 \mathrm{ml} / \mathrm{h}$ in which higher than without rice bran. It mean rice bran as a source of readily digestible carbohydrates that supply of nutrients for silage inoculant in optimizing fermentation process. It was indicated by the increased gas production. 


\section{Production of Volatile Fatty Acids (VFA) and Ammonia $\left(\mathrm{NH}_{3}\right)$}

Besides the in vitro digestibility parameters, production of VFA, mainly acetate, propionate and butyrate, and $\mathrm{NH}_{3}$ were very important in supporting the needs of nutrients for animal. Synchronization of VFA and $\mathrm{NH}_{3}$ production was significant affect on animal performance. Due to it was a precursor for microbial protein and fat body synthesis of animal. Production of VFA and $\mathrm{NH}_{3}$ from silage during $48 \mathrm{~h}$ incubation is presented in Table 4.

In general, VFA and $\mathrm{NH}_{3}$ production from silage between treatments was not significantly different $(\mathrm{P}<0.05)$. The average production of acetate, propionate and butyrate $105.7,36.2$, and $13.8 \mathrm{mM}$ respectively with the average ratio of acetate $\left(\mathrm{C}_{2}\right)$ of propionate $\left(\mathrm{C}_{3}\right)$ was 2.9. Ammonia production was generally ranges from 22.2 to 25.1
$\mathrm{mM}$ or ranged from 37.7 to $42.7 \mathrm{mg} / 100 \mathrm{ml}$ (Table 4). There was tendency that the higher the addition of bran to produce $\mathrm{NH}_{3}$.

Levels of ammonia in silage with $10 \%$ rice bran showed that $\mathrm{NH}_{3}$ production $4 \%$ higher than silage treated with $0 \%$ and $5 \%$ rice bran. This is related to protein content in silage due to the addition of rice bran. Based on the results of chemical analysis, rice bran contains about $13 \%$ protein so that addition of $10 \%$ rice bran silage resulted in a $1.3 \%$ increase protein content. This results supported by Santoso and Hariadi (2009) stated that concentration of ammonia produced was significant influenced by the chemical composition of feedstuffs especially protein content. Ammonia production from straw corn (CP 11.9\%) resulted higher than rice straw (CP $6.8 \%)(23.0 \mathrm{vs} 8.9 \mathrm{mg} / 100 \mathrm{ml})$.

Volatile fatty acids concentration of rumen fluid produced during the fermentation process is an indicator of energy availability for animal

Table 4. Volatile Fatty Acids (VFA) and Ammonia (NH3) Production In vitro from Silage Incubated for 48 Hours

\begin{tabular}{|c|c|c|c|c|c|}
\hline \multirow{3}{*}{ Treatment } & \multirow{3}{*}{ Parameter } & \multicolumn{3}{|c|}{ Rice Bran Level } & \multirow{3}{*}{ Average } \\
\hline & & $0 \%$ & $5 \%$ & $10 \%$ & \\
\hline & & \multicolumn{3}{|c|}{ 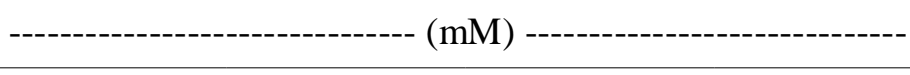 } & \\
\hline \multirow{4}{*}{ Control } & Acetate & 115.56 & 113.74 & 123.12 & 117.47 \\
\hline & Propionate & 37.83 & 42.87 & 38.63 & 39.77 \\
\hline & Butyrate & 12.18 & 13.57 & 21.46 & 15.74 \\
\hline & Ammonia & 23.95 & 23.62 & 22.49 & 23.35 \\
\hline \multirow{4}{*}{ Lp } & Acetate & 104.02 & 112.03 & 101.03 & 105.69 \\
\hline & Propionate & 40.67 & 29.82 & 32.45 & 34.31 \\
\hline & Butyrate & 15.74 & 12.54 & 12.11 & 13.46 \\
\hline & Ammonia & 22.36 & 22.22 & 25.09 & 23.22 \\
\hline \multirow{4}{*}{$\mathrm{Lp}+\mathrm{Sc}$} & Acetate & 110.02 & 100.67 & 71.65 & 94.11 \\
\hline & Propionate & 39.53 & 36.01 & 27.99 & 34.51 \\
\hline & Butyrate & 12.66 & 13.90 & 9.73 & 12.10 \\
\hline & Ammonia & 23.06 & 23.23 & 24.55 & 23.61 \\
\hline \multirow{4}{*}{ Average } & Acetate & 109.87 & 108.81 & 98.60 & \\
\hline & Propionate & 39.34 & 36.23 & 33.02 & \\
\hline & Butyrate & 13.53 & 13.34 & 14.43 & \\
\hline & Ammonia & 23.12 & 23.02 & 24.04 & \\
\hline
\end{tabular}

Lp: L. plantarum; Sc: S. cerevisie 
(Jayanegara et al., 2009b). It components consisted of acetate, propionate and butyrate absorbed through the rumen wall and used as a source of energy in various organs of cattle through oxidation of tricarboxylic acid cycle (Hungate, 1966). Concentrations of VFA in the rumen was influenced by type of substrate / feed consumed by ruminants. Total VFA in the rumen of cattle consuming grass silage about $108 \mathrm{mM}$ with $74 \%$ the proportion of acetate $(79.9 \mathrm{mM})$, propionate $17 \%(12.6 \mathrm{mM})$ and butyrate $7 \%(1.2$ $\mathrm{mM})$.

Production of VFA and the proportion of acetate, propionate and butyrate might be changed with supplementation of feed concentrate (McDonald et al., 2002). According to Owens and Goetsch (1988), stated that total VFA in rumen of cattle consumed concentrations higher than cattle consumed hay (150 vs. $100 \mathrm{mM})$. Further stated that the proportion of acetate: propionate: butyrate in cattle rumen that consumed concentrate was 50:40:10, while the cattle consumed hay was $65: 25: 10$

\section{CONCLUSION}

The use of lactic acid bacteria - yeast consortium inoculant consisted of $L$. plantarum and $S$. cerevisiae in making of grass silage increased in vitro digestibility and fermentability, reduce contamination of clostridia in silage without negative effect on production of VFA and $\mathrm{NH}_{3}$.

\section{REFERENCES}

Blümmel, M., H. Steingass and K. Becker. 1997. The relationship between in vitro gas production, in vitro microbial biomass yield and ${ }^{15} \mathrm{~N}$ incorporation and its implications for the prediction of voluntary feed intake of roughages. Br. J. Nutr. 77:911-921

Broderick, G. A. and J. H. Kang. 1980. Automated simultaneous determination of ammonia and total amino acids in ruminal fluid and in vitro media. J. Dairy Sci. 63:64-75

Chaucheyras, F., G. Fonty, G. Bertin and P. Gouet. 1995. In vitro utilization by a ruminal acetogenic bacterium cultivated alone or in association with an Archea methanogen is stimulated by a probiotic strain of Saccharomyces cerevisiae. Appl. Environ. Microbiol. 61: 3466-3467

Chen, X.B. 1997. Neway-Excel Microsoft Office:
A Utility for Processing Data of Feed Degradability and In vitro Gas Production. Rowett Research Institute. Aberdeen, UK.

Filya, I. 2003. The Effect of Lactobacillus buchneri and Lactobacillus plantarum on the fermentation, aerobic stability, and ruminal degradability of low dry matter corn and sorghum silages. J. Dairy Sci. 86:35753581

Gobbetti, M. 1998. The sourdough microflora: interactions of lactic acid bacteria and yeasts. Trends Food Sci. Technol. 9:267-274

Gollop, N., V. Zakinand and Z.G. Weinberg. 2005. Antibacterial activity of lactic acid bacteria included in inoculants for silage and in silages treated with these inoculants. J. Appl. Microbiol. 98: 662-666

Gomez, K.A. and A. A. Gomez. 1984. Statistical Procedures in Agricultural Research. $2^{\text {nd }}$ edition. John Wiley \& Sons, New York.

Hungate, R.E. 1966. The Rumen and Its Microbes. Academic Press, New York.

Jayanegara, A., A. Sofyan, H.P.S. Makkar and K. Becker. 2009a. Kinetika produksi gas, kecernaan bahan organik dan produksi gas metana in vitro pada hay dan jerami yang disuplementasi hijauan mengandung tanin. Med. Pet. 32 (1): 120-129

Jayanegara, A., H. P. S. Makkar and K. Becker. 2009b. Emisi metana dan fermentasi rumen in vitro ransum hay yang mengandung tanin murni pada konsentrasi rendah. Med. Pet. 32(3):184-194

Mannetje, L. 2000. Introduction to the conference on silage making in the tropics. L.'t Mannetje (ed.) Proc. of the FAO Electronic Conference on Tropical Silage. September 1- December 15, 1999. pp. 1-4

McDonald, P., A.R. Henderson, and S.J.E. Heron. 1991. The Biochemistry of Silage. Second Edition. Chalcombe Publications, Marlow, UK.

McDonald, P., R.A. Edwards, J.F.D. Greenhalgh and C.A. Morgan. 2002. Animal Nutrition. Sixth Edition. Prentice Hall, London.

Menke, K. H., L. Raab, A. Salewski, H. Steingass, D. Fritz and W. Schneider. 1979. The estimation of the digestibility and metabolisable energy content of ruminant feedingstuffs from the gas production when they are incubated with rumen liquor. J. Agric. Sci. 93:217-222

Montvile, T.J. and K. Winskowski, 1997. Biologically based preservation system and 
probiotic bacteria. In: Doyle, M.P., L.R. Beuchat and T.J. Montvile (Eds). Food Microbiology, Fundamentals and Frontiers. American Society for Microbiology. Massachusetts Ave, Washington. pp. 557577

Nishino, N., H. Wada, M. Yoshida and H. Shiota. 2004. Microbial counts, fermentation products, and aerobic stability of whole crop corn and a total mixed ration ensiled with and without inoculation of Lactobacillus casei or Lactobacillus buchneri. J. Dairy Sci. 87:2563-2570

Ørskov, E. R. and I. McDonald. 1979. The estimation of protein degradability in the rumen from incubation measurements weighted according to rate of passage. J. Agric. Sci. 92:499-503

Owens, F.N. and A.L. Goetsch. 1988. Ruminal fermentation. In: Church, D.C. (Ed). The Ruminant Animal Digestive Physiology and Nutrition. Prentice Hall, Englewood Cliffs, New Jersey. pp.145-171

Santoso, B. and B.T. Hariadi. 2009. Evaluation of nutritive value and in vitro methane production of feedstuffs from agricultural and food industry by-products. J. Indonesian Trop. Anim. Agric. 34(3):189-195

Sofyan, A., R. Utomo, L.M. Yusiati and Y.
Widyastuti. 2011. Isolation and identification of lactic acid bacteria and Saccharomyces cerevisiae from natural sources as feed-silage inoculants. Proceeding of the 3rd International Conference of Indonesian Society for Lactic Acid Bacteria (ISLAB). Yogyakarta, 21-22 January 2011. pp. 89-96

Stefanie, J.W.H., O. Elferink, F. Driehuis, J.C. Gottschal and S.F. Spoelstra. 2000. Silage Fermentation and Their Manipulation. In: L.' $t$ Mannetje (ed.) Proc. of the FAO Electronic Conference on Tropical Silage. September 1- December 15. pp. 17-30

Strauss, C.J., J.L.F. Kock, P.W.J. van Wyk, E.J. Lodolo, C.H. Pohl and P.J. Botes. 2005. Bioactive oxylipins in Saccharomyces cerevisiae. J. Inst. Brew. 111 (3):304-308.

Thuault, D., E. Beliard, J.L. Guern and C.M. Bourgeois. 1991. Inhibition of Clostridium tyrobutyricum by bacteriocin-like substances produced by lactic acid bacteria. J. Dairy Sci. 74:1145-1150

Vissers, M.M.M., F. Driehuis, M.C. TeGiffel, P. De Jong and J.M.G. Lankveld. 2007. Concentrations of butyric acid bacteria spores in silage and relationships with aerobic deterioration. J. Dairy Sci. 90:928936 